companions (one canine) was positioned upstream of the junction, and we poured milk (UHT skimmed, Intermarché, Hesdin, Pas-de-Calais) in a thin stream from each side of the hull so that one stream tended to flow towards the river and the other towards the mill stream. The flow was largely laminar, and the streamlines remained remarkably coherent and showed little deviation during the course of the experiment (about 30 seconds). Photographs were taken but, disappointingly, navigational and other inexplicable stability problems rendered them unfit for publication. Fortunately this type of flow behaviour is well known on a larger scale from aerial views of the sediment carried by converging tributaries of rivers carrying glacial melt water, in which streamlines consisting of sediment from the two sources travel side by side for many miles without mixing.

The observation that prompted Knight's study is of considerable interest, and the hypothesis and experimental results are thought provoking. The possibility of predicting the likelihood of repeated transient ischaemic attacks suggests that more formal modelling of the system as well as numerical simulations of the shedding, transport, and capture of emboli would be a worthwhile enterprise both clinically and scientifically.

Competing interests: None declared.

Knight R. The Poohsticks phenomenon. BMJ 2004;329:1432-3.

Lorenz EN. Deterministic non-periodic flow. J Atmospheric Sci $1963 ; 20: 130-41$.

\title{
Commentary: A Fee-Nom-in-Hum and an Expotition
}

\author{
Julie Morris
}

South Manchester

NHS Trust,

Wythenshawe

Hospital,

Manchester

M23 9LT

Julie Morris

head of medical

statistics

julie_m@

fs1.with.man.ac.uk
This paper by Knight $^{1}$ describes a great Expotition into the 100 Aker Wood to investigate the puzzle, "Isn't it funny how emboli race to the same place?" by throwing pine cones from My Bridge into the stream and tracking them, in a Big Adventure, to see where they would end up.

The study seems very interesting, and the results would make my friend Eeyore think, "That accounts for a Good Deal. It Explains Everything. No Wonder." But I am not sure I understand everything the Clever Dr Knight has described. For example, when was this Expotition carried out? "On Monday, when the sun is hot" or "On Tuesday, when it hails and snows"? This matters because the stream changes with the weather.

How many investigators came to the bridge? And how did they carry so many pine cones? Did they bring enough Provisions for such a Big Adventure? And did they sing,

"How sweet to be a cone

Floating in the stream

Every little cone

Always sings alone"?

It isn't surprising that some cones stopped in the same place. I assume there were Big Stones and Rox, and the cones went, Bump, Bump, Bump against these or other Cunning Traps.

As a Bear of Very Little Brain I asked my friend Owl, who always knows something about something, to calculate how likely it is that so many cones end up at the same place. He said that assuming there were only seven different places, A, B, C, D, E, F, and "other" (for the cones that were assumed to have drifted further downstream $^{1}$ ), then the probability of getting 31 or more (out of 100) at just one place was much smaller than $\mathrm{P}<0.0001$ (assuming a binomial distribution and equal probabilities of getting to each of the seven places). I said to him, "I see, I see," but I didn't quite understand, as long words Bother Me.

The last point that worries me is: what happened to all those red pine cones? Did the investigators collect them all up? Or will I have to do it? I suppose I could use Christopher Robin's umbrella, and my friends Piglet and Eeyore could help. But, it reminds me of the Very Great Danger during the Terrible Flood. Anyway, perhaps the Woozle or Heffalump ate them?

Now I am Very Tired and I think I shall Stop There and eat my Provisions.

Winnie-the-Pooh.

With apologies to A A Milne. Extracts from Winnie the Pooh, by A A Milne, were quoted by permission of the trustees of the Pooh Properties.

Competing interests: Anything connected to Hunny.

1 Knight R. The Poohsticks phenomenon. BMJ 2004;329:1432-3.

\section{A conflict of interest?}

\begin{tabular}{|c|c|}
\hline Level 7A & surgical outpatients \\
\hline Level 6B & Medical Outpatients \\
\hline Level 5 & Dermatology Outpatients \\
\hline Level 4 & $\begin{array}{l}\text { Appointments Office } \\
\text { Medical Records } \\
\text { Medico-Legal Dept }\end{array}$ \\
\hline Level 3B & Genito Urinary Medicine Discharge Lounge \\
\hline Level 3A & $\begin{array}{l}\text { Department of Rehabilitation Medicine } \\
\text { Physiotherapy \& Occupational Therapy }\end{array}$ \\
\hline Level 2 & $\begin{array}{l}\text { Accident \& Emergency } \\
\text { Accident \& Emergency X-ray Ward Admissions } \\
\end{array}$ \\
\hline
\end{tabular}

This sign is genuine. The title of the level 3B lounge in the outpatient block of the Royal Victoria Hospital, Belfast, is unfortunate, given its site.

James A Patterson, specialist registrar

(jamesapatterson@hotmail.com), Adrian K Neill, specialist registrar, Keith Mulholland, research fellow, William D Wallace, research fellow, department of surgery, Queen's University Belfast, Belfast BT12 6BJ 